\title{
REPRESENTATIONS OF MEMORIES THROUGH ART: THE ARTISTIC WORK OF ZDRAVKO DUČMELIĆ IN ARGENTINA
}

\author{
Nadia MOLEK', Juan Carlos RADOVICH", Juan Esteban DE JAGER"', \\ Amalia PEREZ MOLEK"II
}

COBISS 1.01

\begin{abstract}
Representations of Memories through Art: The Artistic Work of Zdravko Dučmelić in Argentina This article discusses the topic of representations of memories through art using an interdisciplinary approach that connects contributions from the fields of anthropology and art history to the research problems of art and creative processes. Considering the artistic world of the Croatian painter Zdravko Dučmelić in Argentina as a case study, the main aim of the article is to explore how the sum of the acquired artistic/aesthetic habitus that mediated his artistic activities, memories and personal experiences was combined in the artist's creative process. To this end we will present the formation of Dučmelić's artistic and aesthetic habitus, and his insertion into the Argentinian sociocultural and artistic context, in order to explore Dučmelićs creative process, paying special attention to the way that personal experiences, emotional stimuli and memories were resignified into artistic, symbolic and oneiric images. KEY WORDS: Dučmelić, art, creative process, memories, Croatians in Argentina, interdisciplinary approach
\end{abstract}

\section{IZVLEČEK}

Reprezentacije spominov skozi umetnost: Umetniško delo Zdravka Dučmelića v Argentini

Avtorji v članku predstavljajo umetniški svet hrvaškega slikarja Zdravka Dučmelića v Argentini. Spominjanje s pomočjo umetnosti in kreativnosti obravnavajo $\mathrm{z}$ interdisciplinarnim povezovanjem antropologije in umetnostne zgodovine. Raziskujejo izražanje pridobljenega umetniškega in estetskega habitusa ter združevanje spominov in osebnih izkušenj v umetniškem ustvarjalnem procesu. S tem namenom predstavijo Dučmelićev estetski in umetniški habitus in njegov vstop v argentinski sociokulturni in umetniški prostor. Posebno pozornost posvečajo transformaciji osebnih in čustvenih izkušenj in spominov v umetniške simbolne in sanjske podobe.

KLJUČNE BESEDE: Dučmelić, umetnost, umetniški proces, spomini, Hrvati v Argentini, interdisciplinarni pristop

PhD candidate, Universidad de Buenos Aires, Facultad de Filosofía y Letras, Instituto de Ciencias Antropológicas, Puan 470, Ciudad de Buenos Aires, Argentina; nadiamolek@gmail.com; Lecturer at Universidad del Salvador, Argentina; Visiting researcher at Inštitut za slovensko izseljenstvo in migracije ZRC SAZU, Ljubljana, Slovenia.

॥ PhD Anthropology, Lecturer at Universidad de Buenos Aires, Facultad de Filosofía y Letras, Instituto de Ciencias Antropológicas, Puan 470, Ciudad de Buenos Aires, Argentina; radovich@retina.ar; Researcher at C.O.N.I.C.E.T., Argentina.

III BA, Universidad de Buenos Aires, Facultad de Filosofía y Letras, Instituto de Ciencias Antropológicas, Buenos Aires, Argentina. Puan 470, Ciudad de Buenos Aires, Argentina; juandejager@ gmail.com

IIII PhD Anthropology, Lecturer at Universidad de Buenos Aires, Facultad de Filosofía y Letras, Instituto de Ciencias Antropológicas, Puan 470, Ciudad de Buenos Aires, Argentina; radovich@retina.ar; Researcher at C.O.N.I.C.E.T., Argentina. 


\section{INTRODUCTION}

Every artistic creation is constrained by sociocultural, historical, institutional and other contextual facts experienced by the artist. Art and art history, like other social phenomena, are products of social, political and economic relationships. Setting art objects, artists' biographies, and the evolution of stylistic sequences in contexts of perceptions brings them closer to long-standing anthropological concerns and interests, avoiding the view of art history as the pristine, apolitical study of aesthetic forms (Price in Goldstein 2010: 1). Based on contemporary art studies in anthropology (Schneider 2006; Svašek 2007; Price in Goldman 2010), we will present the artistic work of the Croatian artist Zdravko Dučmelić in the context of his migration process from Croatia to Argentina, in order to address complex connections between artworks and visual representations of memories, within the social relationships in which they occur. We are especially interested in exploring the artist's configuration of style, his perceptions about art, his creativity process and the sublimation of personal experiences through the artistic process, specific techniques and aesthetics.

For this purpose, we will juxtapose the art worlds (Schneider 2006) and artist's life story with broader socio-historical contexts. Firstly, we will begin by exploring how Dučmelić configured his aesthetic habitus ${ }^{1}$ in Europe. We will then present his insertion into the Argentinian sociocultural and artistic context. The last two sections will focus on Dučmelić's art production. We want to analyse how his artistic habitus and memories of the war converged in his art practices, both in his individual work and in his collaboration with Jorge Luis Borges. Our main hypothesis is that the artist comprises the sum of his acquired skills, knowledge and abilities that mediate his artistic activities, i.e. an artistic/aesthetic habitus, but that his creative process also involved representations of social memories and personal experiences. The methodology used to achieve our central goal consists in establishing an interdisciplinary dialogue between art and anthropology. We find that visuality, as a culturally configured practice, finds a central place in our research. We emphasise that focusing on research of Dučmelićs visual images, conceiving them in terms of scientific relevance (Schneider, Wright 2013), will allow us to understand the creative process, the appropriation and configuration of Dučmelićs artistic and aesthetic habitus. In addition, in this initial approach, we focused the research on secondary sources such as biographies, media interviews, interviews by other artists and critics, catalogues of his works, and literature related to his artistic oeuvre, in order to reconstruct the cultural, artistic and political-economic context of Argentina at the time of Dučmelićs arrival and to describe Dučmelić's creative process in Argentina.

\section{NOTES ON ART AND ANTHROPOLOGY}

Classical anthropological approaches have focused on art as a part of a cultural complex and capabilities acquired by a human being as a member of society (e.g.: Tylor 1871). These

1 According to Bourdieu (1984: 17), habitus is a system of schemes that constantly guides choices. Bourdieu (1984) strongly argues that art, like many other social practices, is a field which includes contextualized and politicized agents and their interaction. His concept of habitus leads us to understand the individual/structure relationship and the conditions that structures impose to the individuals, required in order to occupy any position in the social field. 
proposals sought to discover "uncorrupted artistic traditions" among "isolated primitive people" and have concentrated on the separate domain of "aesthetic objects (or practices)" and "styles" that exists in various "non-western" cultures ${ }^{2}$ (Marcus, Meyers 1995). ${ }^{3}$ Others have been deeply involved in challenging the universality and essentialism of the category of art. One of anthropology's leading figures, Claude Levi-Strauss (1968, 1981), used a structuralist approach to address the meaning of art in order to conceptualize the universal structures of the mind, which he believed operate based on pairs of binary oppositions. ${ }^{4}$ Other anthropologists have highlighted the analogy between art and language. Anthony Forge $(1967,1973)$ stated that rules for the combination of elements in art could be equivalent to syntax in language. ${ }^{5}$

Symbolic anthropology has also made considerable contributions. Symbolic anthropologists mainly conceive humans as "homo simbolicus" (Cassirer 1968), who have a need to create symbols, and therefore works of art, to which humans assign meanings (Des Chene 1996: 1274). The creation of artistic symbols can reveal the deep intrinsic connection of the symbolic imagination and the social imaginary with art. Using this paradigm, Clifford Geertz (1994) stressed that art is a part of a cultural system. For Geertz, symbols are "vehicles of culture", meaning that symbols should be studied for what they can reveal about culture and "ways of perceiving the world" (Geertz 1994: 119). This perspective turned anthropology towards issues of interpretation and hermeneutical approaches.

Current multifocal anthropological approaches to art include the crossing of interdisciplinary boundaries: art history literature, artists demanding an interpretive role, and the influx of voices from previously underrepresented groups are all gaining momentum (Price in Goldman 2010: 5). These perspectives call for the abandoning of Eurocentric and "discipline-centric" perspectives, which focused on cultural isolates, and moved to set the societies and cultures into broader contexts, hybrid discourses and interdisciplinary approaches such as cultural studies, visual anthropology, sociological and art historical contributions and even collaborations between art and anthropology (Strolm 2012). The globalization process presents new challenges and needs for redefining intercultural conversations about the nature and meaning of art in all its varied settings. Art is spread globally (Coote, Shelton 1992; Marcus, Myers 1995; Schneider 2012; Price in Goldman 2010; Schneider, Wright 2013) and scholars are no longer constrained by the stylistic essences of particular arts in particular cultures or within particular bounded communities, but with critical anthropologies and sociologies of art, which propose more complex views that overlap "art worlds" (Schneider 2006) as historically and socially situated (Marcus, Meyer 1995), challenging the traditional cultural geographies of art and the hierarchies of traditional art scholarship. New approaches focus on art objects as products of social agency within a society, that is, the way in which they are used and interpreted in social

2 Cf. Coote, Shelton 1993.

3 Franz Boas, for instance, studied the artistic aesthetic of the Pacific Northwest Coast of North America, describing the style as a resulting interaction of environment, materials, tools, and cultural patterns (Boas 1927).

4 Levi Strauss $(1968,1981)$ explored the human propensity to create classification systems, demonstrating in his analysis of Kwakiutl's Xwexwe and Salish's Swaihwe masks that the meaning of an element or object is revealed when it appears as an element within a structural system of social relationships.

5 Forge studied the art of New Guinea's Abelam and Iatmul people. 
relations makes them meaningful (Gell in Schneider 2006) and also in relation to cooperative, multi-layered processes between a number of individuals (producers, mediators, and recipients), institutions, and art objects, not just as the result of a creative act by a single individual, commonly denominated "the artist" (Becker in Schneider 2006).

\section{CONFIGURATION OF DUČMELIĆ'S ARTISTIC AND AESTHETIC HABITUS}

Zdravko Dučmelić (1923-1989), considered by art historians as a surrealist and metaphysical artist, was born in Vinkovci, a town in the Slavonia region of eastern Croatia, ${ }^{6}$ where he finished secondary school. The young artist's life was strongly impacted by World War II. He was studying at the Royal College of Arts and Crafts in Zagreb when he was forced first to mobilize and then into exile. Dučmelić escaped being killed in the event known as the Bleiburg massacre. ${ }^{7}$ This event together with the persecution of political opponents of the communist revolution caused a mass emigration of Croats at the end of the Second World War. They fled to refugee camps in Austria and Italy, where the diasporic community was founded, before emigrating again to Argentina, ${ }^{8}$ the United States and Australia. He held his first exhibition while staying at a refugee camp in Fermo, Italy.

In exile, Dučmelić institutionalized his artistic/aesthetic habitus in a formal academic context. He gained a rich and cosmopolitan artistic training through various formative experiences in Rome and Madrid, ${ }^{9}$ where he continued briefly to study. During this period he also established contacts with other European cultural and art epicentres in Hungary, Austria and France. Zdravko Dučmelić's art worlds can be seen as structuration of aesthetic schemes and techniques, historically situated in the vanguard movements, as well as within the social contexts and social relationships and migration experiences experienced by the artist. His technique and aesthetics were influenced by the Spanish painters Francisco Goya y Lucientes (1746-1828) and Jose Solana Gutiérrez (1886-1945), the Italians Giorgio de Chirico (1888-1978) and Mario Sironi (1885-1961), as well as by universal painting and art history, and particularly by various avant-garde movements of the twentieth century. The Italian metaphysical art movement ${ }^{10}$ can also be perceived in his mental vision, expressed with stone grey and still landscapes, unnaturally empty, lacking

$6 \quad$ At that time, Croatia was a part of the Kingdom of Serbs, Croats and Slovenes.

7 After the end of World War II, tens of thousands of soldiers and civilians associated with the Axis fleeing Yugoslavia were repatriated to that country. Thousands were murdered or forced into concentration camps. The events are named for the Carinthian border town of Bleiburg, where the main repatriation was conducted.

8 Between 1945 and 1956, Argentina received approximately 35,000 Croatian political exiles. This immigration wave was characterized by being composed of a large number of professionals and intellectuals with a strong Croatian nationalistic ideology. They established an introverted ethnic community based on shared experiences of exile, strong political stances, Catholicism, and the commitment to preserve "Croatian culture and identity".

9 In Madrid he was awarded a Spanish Catholic University Deed Scholarship to study at the Real Academia de Belles Artes de San Fernando.

10 Metaphysical Art (a translation of the Italian Pittura Metafisica) was an early twentieth century Italian art movement typified by dream-like views of arcaded squares with unexpected juxtapositions of objects (www.tate.org.uk). 
vegetation, flooded with nostalgia and loneliness, where human emotion is replaced by rationality and a realistic style (Studia Croatica 1968, 1972, 1988; Hočevar 2009). Surrealism and oneiric, dream-like imagery stimulated his interest in dream-like fantastic imagery as well, especially through the work of Max Ernst (1891-1976), and once settled in Argentina, through Roberto Aizenberg's (1928-1996) automatism ${ }^{11}$ and Xul Solar's (1887-1963) symbolism (ibid.). Nevertheless, Dučmelić didn't consider himself a “blind follower", arguing that "I found no artist to follow" (ibid. 1988). Many critics agree with this statement. For them, Dučmelić was a gifted painter with an extraordinary technique, but one who didn't follow any formal art movements (ibid.: 1968, 1988).

Dučmelićs palette was characterized by the use of dark, cold colours: blacks, greys, blues and ochres. The institutionalization process of "a few colours" that rendered in his particular and expressive stylistic habitus was formed in Spain: "This Spanish palette with blacks, greens ... these ochres ... are the natural landscapes of Spain, which I always kept. Since my first oils, I have remained faithful to this palette of colours, perhaps ten or twelve, but no more ..." (Studia Croatica 1988) His work recalled the typical monochrome painting and abstraction of the early twentieth century. The reduced use of images, the search for purity, looked to express neutrality, serenity and rationality.

The architect and painter Sergio Hočevar (2009), a Yugoslav descendant who spent a great deal of time with Dučmelić in Mendoza, pointed out that the rigid academic discipline acquired in Europe allowed the Croatian artist to combine different techniques and materials that could suit his creative process. He created paintings, sculptures and graphics, working with pencil, tempera, oils, water-based inks and acid baths, eggs, brushes, sharp edges, feathers and other tools he made himself, depending on the creative process in which he was immersed. On the other hand, Dučmelićs compositions reflected a crisis of aesthetic reception, where the traditional roles of the artist-viewer relationship are strained. His early immersion in avant-garde techniques and aesthetics led him to break with the "classical" art theory requirement of a unique view postulated by the artist. For Ruiz Días, the artist wanted to force the viewer to invent a way of perceiving the work (ibid.: 1968), suggesting that artwork only exists in their interpretation, opening multiple meanings for the observer (Eco 1992). In summary, Dučmelić was a creator who melded tools, materials and mixed heterogeneous influences together according to the aesthetics and inspirational factors he had at hand, closer to the qualities of his senses than to formal theories and movements. If we want to interpret his process of artistic creation, we can see his art as a product of "bricolage" (Levi Strauss 1970), without fixed meaning, but continuously acquiring new meanings, depending on the changing contexts in which it operates.

11 In art, automatism usually refers to the accessing of material from the subconscious or unconscious mind as part of the creative process - as seen in the art of the surrealist movement (www. tate.org.uk). 


\section{THE INSERTION OF DUČMELIĆ INTO THE ARGENTINIAN SOCIOCULTURAL AND ARTISTIC CONTEXT}

Although Dučmelić can be regarded as a case study about the search for universal symbolism and mythology through metaphysical and surrealist philosophy and its convergence with the specific artist's experience, his artistic and intellectual production must be contextualized within the social construction of art practices and movements in Argentina. The political programmes of the late $19^{\text {th }}$ Century defined Argentina as an immigrant country, ${ }^{12}$ and Buenos Aires became known as the "Paris of South America" (Schneider 2006: 6). ${ }^{13}$ In the context of nation building, dominant Argentinian politicians privileged European culture over any autochthonous traditions. Argentineans should be the result of "uprooted and transplanted Northern Europeans" who would "civilize and cultivate the spirits". Thus, the building process of the Argentinian art world begins to be institutionalized and centred in Buenos Aires within this philosophical approach, in the context of nation-state formation (ibid.).

In the early twentieth century, the Buenos Aires elite sought their models of cultural and artistic reference primarily in Europe. Artists, musicians and writers would move to France or Italy to spend long "building internships". For example, the plastic works of the so-called Generación del 80 (Generation of 1880) artists ${ }^{14}$ brought the European aesthetic of Realism. ${ }^{15}$ Impressionism and Post-Impressionism were introduced by the artist Martin Malharro (1865-1911) after a long stay in Paris. These techniques were especially in sync with the cultural nationalism of those years. The Northern European immigrants that the $19^{\text {th }}$ century political intellectuals had dreamed of never came to the country in large numbers. Most of the immigrants were Italian, followed by Spanish and then French (Devoto 2009). In addition, mass immigration brought some unforeseen consequences, such as a reluctant attitude towards "Argentinization". Consequently, the early twentieth century witnessed the emergence of a nationalist movement opposed to foreign influences and the growing immigrant population, which they viewed as a threat to the nation (Delaney 2002: 625). A vigorous movement of literature, philosophy and art that promoted an ethnocultural vision of Argentinian identity rose up. Specifically in art, rural landscapes, costumbrist scenes and "typical characters" were common among the nationalist visual imaginaries.

During the 1920s and 1930s, the panorama of Argentinian art was very heterogeneous, and an artistic revival occurred, based on contemporary European art movements. The

12 Consequently, Argentinian art excluded any indigenous or native influence, and "imported" reference cultural frameworks from Europe and North America. This imaginary still persists among a section of the Argentinian population.

13 Between 1880 and 1930, and after World War II until the early 1950s, Argentina was seen as a European immigrant nation. It received more immigrants than Canada and Australia, and was second only to the United States in terms of the volume of immigration of European origin (Schneider 2006: 9).

14 The Generation of ' 80 served as the governing elite in Argentina from 1880 to 1916.

15 Realism was a mid-nineteenth century artistic movement characterized by subjects from everyday life painted in a naturalistic manner; however the term is also generally used to describe artworks painted in a realistic, almost photographic manner (www.tate.org.uk). 
early avant-gardes such as Futurism ${ }^{16}$ and Dadaism ${ }^{17}$ revivified the artistic language. ${ }^{18}$ Artists who heralded the artistic revival, denominated as vanguards or los Artistas del Pueblo ${ }^{19}$ (People's Artists) began to burst onto the scene. Avant-garde artists, such as the cubist ${ }^{20}$ painter Emilio Pettoruti (1892-1971) and sculptor Pablo Curatella Manes (1891-1962), questioned the dominant Realism and Impressionism. For example, Pettoruti's cubism, which fragmented human figures, scandalized the traditional elites, who claimed that his art gets away from the imitative essence of art. Meanwhile, Surrealism was beginning to stand out. Among the most important artists, we can mention Xul Solar (1887-1963), Antonio Berni's (1905-1981) surrealist period and the brief era of the "Orion Group".

By the late 1930s, literary and cultural magazines such as the renowned Martín Fierro - to which Jorge Luis Borges ${ }^{21}$ (1899-1986) contributed - and the socialist La vanguardia, had an important role in the discussion of brand-new aesthetic ideas. Simultaneously, an "alternative" called Argentinian Modernism began to develop. ${ }^{22}$ Towards the end of the Second World War and within the historical-political context of the rise of Peronism, the Argentinian art scene suddenly became orientated towards the radically non-figurative abstract art known as Concrete Art. ${ }^{23}$ This was the artistic context that greeted Zdravko Dučmelić upon his arrival in Argentina in 1949, together with almost 10,000 other Croatians (Radovich 2016; Gadze, Rajkovic 2016). ${ }^{24}$ The Croatian migration process to Argentina after the Second World War was similar to other exiles of the time. Between 1947 and 1949, Argentina accepted a significant number of refugees from Slovenia, Croatia, Ukraine,

16 Futurism was an early twentieth-century Italian art movement that aimed to capture the dynamism and energy of the modern world (www.tate.org.uk).

17 Dada was an art movement formed in Zurich during the First World War as a negative reaction to the horrors and folly of the war. The art, poetry and performance produced by Dada artists is often satirical and nonsensical in nature (www.tate.org.uk).

18 Meanwhile, other art movements, such as French Purism, the Italian Novecento movement and Germany's Neue Sachlichkeit postulated a modern classicism through the recovery of "pure plastic" values. However, the "traditional-realistic" Nexus group, with members like Fernando Fader (1882-1935) and Cesareo Bernaldo Quirós (1879-1968), was still dominant on the art scene.

19 Los Artistas del Pueblo were the first Argentinian artists who combined aesthetics and a political artistic programme (Muñoz 2000).

20 Cubism was a revolutionary new approach to representing reality invented in around 1907/08 by Pablo Picasso and Georges Braque, who aimed to bring different views of subjects (usually objects or figures) together in the same picture, resulting in paintings that appear fragmented and abstracted (www.tate.org.uk).

21 Borges was an Argentinian short-story writer, essayist, poet and translator, and a key figure in Spanish-language and world literature. As we will show below in this article, he was friends with Dučmelić, who collaborated with him on one of his books. Among the abovementioned artists, Xul Solar also collaborated closely with Borges.

22 Among the most important artists, we can mention: Horacio Butler, Héctor Basaldúa, Lino Enea Spilimbergo, Juan del Prete, Alfredo Guttero, Norah Borges, and Pedro Figari y Raquel Forner (Muñoz 2000).

23 Concrete art is abstract art that is entirely free of any basis in observed reality and that has no symbolic meaning (www.tate.org.uk). Among the most important painters, we can mention: Manuel Espinosa, Claudio Giróla, Alfredo Hlito, Enio Iommi, Raúl Lozza, Tomás Maldonado, Alberto Molenberg, Lidy Prati, Jorge Souza and the Madí movement, Arden Quin, Rhod Rothfuss, Gyula Kosice, and Martín Blaszko (Muñoz 2000).

24 Béla Solstész states that 35,000 Croatians immigrated to Argentina between 1945 and 1948 (Soltész 2011: 3). Most of them had spent time in refugee camps before leaving Europe. 
Poland, Hungary, Austria and Germany who had presumably collaborated with the Nazis during the Second World War (Senkman 1992). ${ }^{25}$ Gadze and Rajkovic (2016) state that approximately 20,000 Croatians were admitted into Argentina between 1946 and 1952. Most of them were political exiles, who came from all over Croatia. The Croatians established themselves particularly in the provinces of Buenos Aires, Santa Fé, Córdoba, Chaco and the Patagonia region (Gadze, Rajkovic 2016). Dučmelić's memories of his reasons for coming to Argentina alluded as much to practical reasons as to spiritual motivations:

While I was studying in Madrid, I really knew very little about Argentina, but I had already read some things about Borges and I also had certain contacts with the country. This happened around 1948 or 1949, when Borges did not yet enjoy worldwide fame. So, I said to myself, if this country has such a personality, it must be worth a lot [...] So I came to these shores, where I found a good place to work. (Studia Croatica 1988)

Dučmelić spent his initial years in Buenos Aires, but the city's subtropical climate and high humidity became very harmful to his health. As a result, following medical advice he moved to a city far away from the centre of the art world, Mendoza, in Mendoza Province, where he lived for thirty years. He became very active at Mendoza's academy of art. He was appointed lecturer at the Escuela Superior de Artes de la Universidad Nacional de Cuyo, and between 1963 and 1966 he was appointed the dean of the school, from which he retired in 1980. Later, he was awarded the title of Honorary Professor.

Despite the fact that his aesthetics pursued different styles than had been developed in the Argentinian artistic context to that point, he became recognized in Argentina's art arena. He received numerous awards and held diverse exhibitions in avant-garde galleries, such as Gran Teatro Opera, Joraci, Huemul, Müller, Van Riel, Wildenstein, and Galatea, and the Surrealistic and Metaphysical Art Gallery run by Ora A. Waissman. His work became part of multi-layered processes between the artists, mediators, and recipients (Becker 1982 in Schneider 2006), transcending his individual creative acts. Art critics believe that he benefited from the reputation he had achieved at European exhibitions in the past. On the international level, Dučmelić was invited by the Argentinian Ministry of Foreign Affairs to hold exhibitions of his works in several museums in Japan in 1980. Dučmelić also held exhibitions in Panama, Peru (Lima), Chile (Santiago de Chile), Mexico, Cuba (Havana), Canada (Ottawa) and China (Beijing). In 1983 he held exhibitions in his homeland, in the cities of Zagreb and Rijeka (Radman, Blog).

25 Argentinian economic prosperity, developed through the industrialization process promoted by Peron, brought about a renewed need for immigrants. During this period the government showed a preference for certain groups of immigrants - from Latin Europe, that is to say Italy and Spain, or from Anglo-Saxon countries (Rosan 2002: 31-32), and avoided immigrants who stayed close together and kept their native lifestyle, meaning they could not integrate into Argentinian society (Senkman 1992). Nevertheless, some exceptions were made. In consequence, in 1947, 33,000 people from Yugoslavia were accepted (Rosan 2002). The majority of them were Croatians, followed by Slovenes and Serbs. 


\title{
MEMORIES BECOME ART: DUČMELIĆ'S CREATIVE PROCESS IN ARGENTINA
}

Dučmelić saw his first fifteen years in Argentina as having been spent on a personal search. He felt that this period was focused on his "artistic formation and maturation", a process that ran through "the thirty-year lonely life I went through in Mendoza" (Studia Croatica 1988). The artist's ideas, his disturbing vision of the world and the themes he painted were highly affected by these feelings of loneliness (ibid.). But they also depicted a personal and shared $^{26}$ experience of war and traumatic political persecution. The war had left major wounds. In an interview, Dučmelić stated that art was "a way of salvation": "My artistic work, everything I have done, has cost me a great effort [...] [But] art helps to develop a kind of sense of salvation [...] art is the way to find answers to insoluble situations" (ibid. 1988). Dučmelić's work integrated not only his transnational academic formation but also his immigrant's/exile's experience (Hočevar 2009). His diasporic belonging, homeland and memories are viewed as a vehicle for creativity:

\begin{abstract}
Although he spent most of his life outside Croatia and he still continues to live outside the country, Dučmelić is a typical Croatian painter. His paintings radiate nostalgia for something lost or perhaps never attained. Permanent conflicts, rebellious collapses and protests against the enigmatic but inexorable destiny drive him to create, using his own strength and within his own possibilities, a longing, imaginative and hopeful world, but at the same time always a very fragile world, in danger of vanishing and disappearing at every moment. (Studia Croatica 1972)
\end{abstract}

Mendoza was a place of tranquillity and meditation for the painter. There, he rediscovered a secret hidden landscape which inspired him to express the tragedy, despair, destruction and desolation that he had suffered. This feeling began to be depicted in the dense solitude of some of his famous landscapes and in the silence of his timeless figures. Dučmelić expressed this sublimation process in the following way:

My first paintings depicted spaces, ruins, figures, human figures. Post-war scenes, torched villages, refugees came to my mind all the time. Then this vision of great sadness rose and ran out of the ruins to the sea. But I didn't know the sea. I had never seen the sea. [...] I am not Dalmatian, consequently I am not aware of how the sea reached my painting. But it meant salvation to me. There was the sea, horses ... figures. [...] three years later I went past this and came back to pure deserts. (Studia Croatica 1988)

The depicted worlds acquired their enigmatic forms through colour and composition. He painted walls and stones, which were orderly, and distributed within the compositional space. Dučmelić states:

26 The Croatian community in Argentina, similarly to other diasporic communities with traumatic pasts, formed and preserved social memories about the traumatic causes that forced their exile. For similar cases, see Anwar 1979, Čapo Žmegač 2007, Alaghiozian et al 2009, Molek 2013. 
Those stones in my paintings were constantly moved from one angle to another, because I was looking for a certain harmony. Each painting depicts a long process of displacement from huge stone and soil masses to mysterious and protected places. [...] I'm not locking myself up, but getting stronger; I am creating strengths. (Studia Croatica 1988)

They were stimulated by the artist's profound need. Dučmelić explained that his painting sought to elude the painful present, jumping constantly from past to future and vice versa: "The present moment is painful. [...] Without a parallel illusory life, real life would be very difficult. Therefore, this may explain why there is a certain kind of poetry and a certain kind of paintings" (Studia Croatica 1988). Another of his recurring themes were petrified humans, hieratic and timeless "empty gaze" figures, especially women, that appear immersed in ruins, ancient geometries, and oneiric climates (ibid.). The artist stated:

The themes of my painting are simple to describe: women among ruins or deserts, archaeological landscapes, a woman's face in the foreground, a woman's profile. [...] My figures represent our ancestors, our desired ancestors, our intelligent non-frivolous people. People who lack the tragic sense of human beings [...]. (Studia Croatica 1988)

Human figures in the middle of strange landscapes full of terrifying solitude, without daylight, abandoned houses and deserted streets, represent pictorial metaphors of the rationality and destruction of man (Studia Croatica 1972). The artist described the relationship between the figures and the desert in the following way:

A peculiar atmosphere permeates my work. It has to do with the search for this ancient therapy, this ancient need articulated in the metaphor of the desert, an ancient biblical necessity. [...] The desert implies deep meanings. It has always been the place the prophets went through to resolve trivial problems (I include myself among the latter). But the desert is not only for Christ or the great prophets; the desert also helps us who aren't prophets. Sitting on a stone, we can resolve our problems there, within a certain space where no one bothers you or anybody, a space where the thinker can't be distracted. (Studia Croatica 1988)

The movement of crossing boundaries through figuration and abstraction helped him to rekindle tough social memories and transform them. He sublimated his past into a new subjective, specific, absolute, metaphysical and surrealist reality (Hočevar 2009). In the last twenty years, Dučmelić has reoriented his work (Studia Croatica 1988). He abandoned the obscure impressions of the Second World War and began to allow light and colour to come into his paintings (Hočevar 2009). Hočevar recalled this shift:

And one day I found to my great surprise a series of watercolours he was doing. Women's figures saturated with colours, vibrant, were communicating the beginning of a new artistic and creative period. When Dučmelić noticed my astonishment, he replied "The war is over, and I am living in Mendoza." (Hočevar 2009) 


\section{DUČMELIĆ AND BORGES: THE PROCESSUAL NATURE OF CREATIVITY}

Usually reverie and imagination are not easily found in anthropological texts. But we find it important to consider them as part of Dučmelić's creative process. In 1983, the artist was invited to make an imprint as the illustrator of the famous literary work Laberintos [Labyrinths], written by Jorge Luis Borges. In an interview, Dučmelić stated that his "spiritual affinity" with Borges was circumscribed to the mythological-archaeological aspects of the writer's tales (Studia Croatica 1988). Borges' literary images inspired the artist immediately, finding after an intense creative process the ability to make a pictorial representation of them. He stressed in the interview that he was trying to represent "tigers, mirrors, labyrinths, sand and ... what else? Immortality, infinity and timelessness" (ibid.: 1988). The resulting series of artwork went through several stages and sketch processes. The images published in Laberintos can also be seen as part of a "larger temporal series and experimentations" (Gell in Schneider 2012: 58) during Dučmelić's lifetime with surrealism and metaphysics. The illustrations and paintings that Dučmelić did for Borges show how the artist's aesthetic habitus and his admiration for Borges' literary images converge in materials for an artistic object that reflects the processual nature of creativity (Schneider 2012).

\section{ART WORLDS: BETWEEN AGENCY AND THE SOCIOCULTURAL CONFIGURATION OF IMAGES}

Art can be understood as one of the patterns through which the societies and individuals that take part in them represent and symbolize their historic and social memory (Grüner 2002: 1). Zdravko Dučmelić had experienced a series of traumatic events that forced him into exile. The episodes he witnessed remained vivid in his mind and found form and expression later through his personal interpretations of the artistic languages acquired during his formative periods. In Argentina, Dučmelić underwent a period of meditation and solitary work that resulted in diverse art objects. In this sense, art, as his basic field of creativity, allowed Dučmelić to reflect his personal and collective life experiences, memories, visions and mythologies. Exploring Dučmelić's paintings and recurrent themes allows us to reveal the deep intrinsic connection of his appropriation of available aesthetics and techniques, and the manifestation of symbolic imagination, which can be part of social imagery and a sociocultural configuration, as in the example of his work with Borges, but also a search for sublimation through aesthetics and the inspirational factors he had at hand, closer to the qualities of his senses than to formal theories and movements. 


\section{REFERENCES}

Alaghiozian, Andrea M., Artinian, Juan P., Diyarian, Maida L., Papazian, Alexis, Schneider, Alejandro, Tchilinguirian, Miguel A., Tossounian, Lucila (2009). Marcas diaspóricas en los armenios exiliados en Argentina, http://www.historiaoralargentina.org/attachments/ article/eho2009/Territoriomigracioneidentidad/Alaghiozian-Andrea.pdf (15. 4. 2017).

Anwar, Muhammad (1979). The myth of return: Pakistanis in Britain. London: Heinemann. Boas, Franz (1927). Primitive Art. New York: Dover

Borges, Jorge Luis (1983). Laberintos. Buenos Aires: Ed. De Arte.

Bourdieu, Pierre (1984). Outline of a Sociological Theory of Art Perception, http://web.mit. edu/allanmc/www/bourdieu3.pdf. (25. 3. 2017).

Coote, Jeremy, Shelton, Anthony (1992) (eds.). Anthropology, Art and Aesthetics. Oxford: Clarenton press.

Čapo Žmegač, Jasna (2007). Strangers Either Way: The Lives of Croatian Refugees in their New Home. New York, Oxford: Berghajn Books.

Cassirer, Ernst (1968). Antropología filosófica: Introducción a una filosofía de la cultura. Mexico: F.C.E.

Cultura croata, http://www.culturacroata.com.ar/ (12. 6. 2017).

Delaney, Jeane H. (2002). Imagining "El Ser Argentino": Cultural Nationalism and Romantic Concepts of Nationhood in Early Twentieth-Century Argentina. Journal of Latin American Studies 34/3, 625-658.

Des Chene, Mary (1996). Symbolic Anthropology. Encyclopedia of Cultural Anthropology (eds. David Levinson, Malvin Ember). New York: Henry Holt, 1274-1278.

Devoto, Fernando (2009). La historia de la inmigración en la Argentina. Buenos Aires: Sudamericana.

Eco, Humberto (1992). Obra abierta. Mexico: Planeta Agostini.

Forge, Anthony (1967). The Abelam Artist: Social Organization. Essays Presented to Raymond Firth; M. Freedman. London: Cass, 65-84.

Forge, Anthony (1973). Primitive Art \& Society. London, New York: Oxford University Press, Wenner-Gren Foundation for Anthropological Research.

Gadze, Paula, Rajkovic, Marijeta Iveta (2016). Los croatas de Argentina en Croacia. Etnicidad y migraciones en Argentina (ed. Juan Carlos Radovich). Buenos Aires: Sociedad Argentina de Antropología.

Galería Suipacha, http://suipachagaleria.com.ar/ducmeliczdravko/ (25. 4. 2017).

Galería Van Riel, http://www.vanriel.com.ar/ (3. 3. 2017).

Geertz, Clifford (1994). El arte como sistema cultural. La Interpretación de las Culturas. Barcelona: Gedisa, 117-146.

Goldstein, Ilana Seltzer (2010). Interview with Sally Price. Proa - Revista de Antropologia e Arte 1-2, http://www.ifch.unicamp.br/proa/EntrevistasII/entrevistasallypriceIN.html (23. 4. 2017).

Grüner, Eduardo (2002). El sitio de la Mirada, http://www.sema.org.ar/downloads/SemPrim_02_Gruner.pdf (18.4.2017).

Hernández Belver, Manuel, Prada, Juan Martin (1998). La recepción de la obra de arte y la participación del espectador en las propuestas artísticas contemporáneas. Reis: Revista española de investigaciones sociológicas 84, 45-63.

Hauser, Arnold (1951). Historia social del arte y la literatura. Barcelona: Guadarrama, Punto Omega. 
Hočevar, Sergio (2009). El rigor y la elegancia de un gran creador. Diario Los Andes, 4. 12. 09, http://www.losandes.com.ar/noticia/cultura-460203 (23. 2. 2017).

Levat, Mariano. Zdravko Dučmelić, http://www.artpromenadebsas.com/paint_ducmelic_es.php (3.3.2017).

Levi Strauss, Claude, Charbonier, George (1968). Arte, Lenguaje, Etnología. Méxivo: Siglo XXI.

Levi Strauss, Claude (1970). El pensamiento salvaje. Mexico: F.C.E.

Levi Strauss, Claude (1981). La via de las mascaras. Buenos Aires: Siglo Veintiuno.

Marcus, George, E., Myers, Fred (1995). The Traffic in Culture: Refiguring Art and Anthropology: Refiguring Art and Anthropology. California: University of California Press.

Molek Nadia (2013). Los refugiados eslovenos en la Argentina. Revista Debates Latinoamericanos, 22, http://repositorio.ub.edu.ar:8080/xmlui/handle/123456789/2009 (10. 3. 2017).

Muñoz, Miguel Angel (2000). Trayectos de las artes plásticas en la Argentina del Siglo XX, http://digitalcommons.providence.edu/cgi/viewcontent.cgi?article=1820\&context=inti (30. 4. 2017).

Pintores Inmigrantes, http://www.monografias.com/trabajos55/pintores-inmigrantes/pintores-inmigrantes2.shtml\#ixzz3viqhnIkc (3. 3. 2017).

Radman, Valentino (2013). Zdravko Dučmelić, Borges' favourite painter, https://tinoradman. wordpress.com/2013/03/16/zdravko-ducmelic-borges-favourite-painter/ (3. 3. 2017).

Radovich, Juan Carlos (2016). El proceso migratorio de los croatas de Konavle en la Argentina. Etnicidad y migraciones en Argentina (ed. Juan Carlos Radovich). Buenos Aires: Sociedad Argentina de Antropología.

Rosan, Vesna Ana. (2002), Prácticas diaspóricas: El caso de la comunidad croata en Buenos Aires. Tesis de Licenciatura. Departamento de Ciencias antropológicas, Facultad de Filosofía y Letras. Buenos Aires: Universidad de Buenos Aires.

Schneider, Arnd (2006). Appropriation as Practice: Art and Identity in Argentina. Palgrave. Schneider, Arnd (2012). Anthropology and Art. The SAGE Handbook of Social Anthropology (eds. Richard Fardon, Olivia Harris, Trevor H. J. Marchand, Cris Shore, Veronica Strang, Richard Wilson, Mark Nuttall). Illinois: Sage, 56-71.

Schneider, Arnd, Wright, Christopher (2013). Anthropology and Art Practice. A\&C Black. Senknam, Leonardo (1992). Etnicidad e inmigración durante el primer peronismo. Estudios Interdisciplinarios de América Latina y el Caribe 3/2, http://www7.tau.ac.il/ojs/ index.php/eial/article/view/1258/1285 (30. 3. 2017).

Soltész, Béla (2011). La emigración croata en Sudamérica. Délket Európa - South East Europe $2 / 1$.

Squirru, Rafael (2001). Ducmelic según Squirru, http://artedelaargentina.com/pdf/156.pdf (7. 2. 2017).

Strolm, Kiven (2012). When Anthropology meets Contemporary Art: Notes for a Politics of Collaboration. Collaborative Anthropologies 5, 98-124.

Studia Croatica (1963). La Tragedia de Bleiburg. Edición Especial. Documentos sobre las matanzas en masa de los croatas en Yugoeslavia en 1945, http://www.studiacroatica. org/revistas/010/0010.htm (25. 4. 2017).

Studia Croatica (1972). Zdravko Ducmelic: Óleos. Acerca de la Exposición en la Galería Wildenstein, http://www.studiacroatica.org/revistas/046/04608.htm (7. 2. 2017).

Studia Croatica (1988). El pintor croata-argentino Zdravko Dučmelić, http://www.studiacroatica.org/revistas/112/112/1120401.htm (23. 4. 2017). 
Studia Croatica (1986). Aportes de la colectividad croata a la República Argentina, Vol. 102. Svašek, Maruška (2007). Anthropology, Art and Cultural Production. University of Chicago Press Books.

Tate Modern, www.tate.org.uk. (1. 3. 2017).

Tylor, Edward Burnett (1871). Primitive Culture: Researches into the Development of Mythology, Philosophy, Religion, Language, Art and Custom. Nabu press.

\section{POVZETEK}

\section{REPREZENTACIJE SPOMINOV SKOZI UMETNOST: UMETNIŠKO DELO ZDRAVKA DUČMELIĆA V ARGENTINI}

\section{Nadia MOLEK, Juan Carlos RADOVICH, Juan Esteban DE JAGER, Amalia PEREZ MOLEK}

Avtorji v članku predstavljajo umetniški svet hrvaškega slikarja Zdravka Dučmelića v Argentini. Spominjanje s pomočjo umetnosti in kreativnosti obravnavajo z interdisciplinarnim povezovanjem antropologije in umetnostne zgodovine. Dučmelić se je leta 1923 rodil v Vinkovcih na Hrvaškem. Med študijem umetnosti na Kraljevsko zemaljsko višem obrazovalištu za umjetnost i umjetni obrt v Zagrebu je izbruhnila druga svetovna vojna. Po odhodu iz Pliberka je zbežal v Rim in pozneje v Madrid, kjer je prišel v stik z deli španskega slikarja Francisca Goye y Lucientesa, italijanskega umetnika Giorgia de Chirica, italijanske metafizične umetnosti, nadrealista Maxa Ernsta in drugih avantgardnih umetnikov. Vsi omenjeni so ga navdihovali pri izražanju globokih vtisov, ki jih je ponazarjal $\mathrm{s}$ kamnito sivimi in praznimi pokrajinami brez vegetacije, potopljenimi z nostalgijo in osamljenostjo, kjer človekova čustva nadomešča racionalnost. Avtorji v članku raziskujejo izražanje pridobljenega umetniškega in estetskega habitusa ter združevanje spominov in osebnih izkušenj v umetniškem ustvarjalnem procesu.

$\mathrm{S}$ tem namenom so raziskali njegov vstop v argentinski sociokulturni in umetniški prostor. Umetnik je leta 1949 skupaj z 10.000 Hrvati prišel v Argentino, kjer je začel plodno umetniško kariero v avantgardnem gibanju. Sledil je zlasti delom Roberta Aizemberga in Xula Solarja. Dučmelićeve vizualne podobe so pritegnile tudi Jorgeja Luisa Borgesa, ki mu je v osemdesetih letih ponudil ilustriranje Labirinta, ene njegovih knjižnih mojstrovin. Kot redni profesor je deloval tudi na Universidad de Cuyo. Največ je ustvaril v Mendozi, kjer je med umikom iz javnosti našel način umetniškega izražanja svojega notranjega sveta ter tako s ponavljajočimi temami transformiral $\mathrm{z}$ vojno spodbujene simbolne in sanjske podobe ter žalostne izkušnje in spomine. Slikal je sive kamnite pokrajine z okamenelimi ljudmi, zlasti ženskami, izgubljenimi v osamljenih puščavah. V svojih delih je akademsko znanje združeval z migracijsko/begunsko izkušnjo. Njegovo ustvarjalnost so poganjali pripadnost diaspori ter spomini na domovino in eksil. V tem smislu je Dečmelićevo umetnost mogoče razumeti kot vzorec, $s$ katerim družbe in njeni člani predstavljajo in simbolizirajo zgodovinski in družbeni spomin. Raziskovanje Dučmelićevih slik in njegovih ponavljajočih tem omogoča razkrivanje povezav estetskih sredstev in tehnik s simbolnim svetom, ki niso le del sociokulturne konfiguracije, temveč tudi sublimacija občutliivih tem z estetiko in navdihom kot tudi s formalnimi teorijami in gibanji. 